直線翼ダリウス型水車内部に設置した

円柱型及び楕円柱型ガイドによる性能向上効果の検討

加瀬 篤志 ${ }^{\mathrm{a},{ }^{*}}$ 井出 慎輝 ${ }^{b}$ 川口 清司 ${ }^{a}$

\title{
Evaluation of Effect of the Cylindrical or Ellipsoidal Guide for the Performance Improvement of the Straight Darrieus Water Turbine
}

\author{
Atsushi Kase ${ }^{\mathrm{a},{ }^{*}, \text { Shinki Ide }}{ }^{\mathrm{b}}$, Kiyoshi Kawaguchi ${ }^{\mathrm{a}}$ \\ (Received January 7, 2020; revised February 18, 2020; accepted February 26, 2020)
}

\begin{abstract}
To develop the high performance water turbine for the small hydroelectric power generator, we suggest the some flow guides set inside the straight Darrieus water turbine. The guides shape the cylindrical or ellipsoidal column. When the tip speed ratio $\lambda$ is below 1.0, the power coefficient $C_{P}$ of the water turbine with the cylindrical or ellipsoidal guide is larger than that of the turbine without any guides. Then the cylindrical guide shows the highest $C_{P}$ and the ellipsoidal guides which be set the suitable angle shows comparable $C_{P}$ to that of the cylindrical guide. When the $\lambda$ is above 1.0, the $C_{P}$ of the turbine with cylindrical guide is smaller than that of the turbine without any guides. Then the $C_{P}$ of the turbine with the ellipsoidal guides which have the suitable oblateness and be set the suitable mounting angle are larger than that of the turbine without any guides. Hence, the ellipsoidal guides will be able to rise the $C_{P}$ in wide range of $\lambda$.
\end{abstract}

キーワード：直線翼ダリウス型水車，整流ガイド，回流水槽，小水力発電

Keywords : Straight Darrieus water turbine, Current guide, Water tunnel, Small hydroelectric power generator.

\section{1.はじめに}

近年，再生可能エネルギーの利用が推進されている。 中でも小規模河川や農業用水路，上下水道等を活用した 小水力発電は太陽光や風力といった他の再生可能エネル ギーに比べて安定した発電が可能であり，また未開発の 包蔵量が多いことから注目が高まっている。そこで我々 は，比較的構造が単純で低コストで作製可能な直線翼ダ リウス型水車を小水力発電に利用することを考えた。こ の水車は揚力型であることから，抗力型に比べて高効率 が期待できる。ただし一般的に直線翼ダリウス型水車は,

* Corresponding author. E-mail: kase@eng.u-toyama.ac.jp a 富山大学

干930-8555＼cjkstart富山県富山市五福 3190

University of Toyama

3190, Gofuku, Toyama-shi, Toyama, Japan 930-8555

b 富山大学大学院理工学教育部

干930-8555 富山県富山市五福 3190

University of Toyama, Graduate School of Science and

Engineering for Education

3190, Gofuku, Toyama-shi, Toyama, Japan 930-8555
低周速比の状態での性能が低く起動性に難があり，また 回転トルクの生じる方位角の範囲が限られている等の問 題点が知られている。従って, 小水力発電システムとし て実用化するには，水車自体の性能向上のための何らか の仕組みが必要であると考えられる。

直線翼ダリウス型水車に関する研究はこれまでにも多 くの報告例がある。例えば別府ら (1)は，水車の外側に設 置したディフューザにより水車に流入する流速を増大さ せて性能向上を図っている。しかしこの方法では，占有 空間が肥大化してしまうことが欠点として挙げられる。 また，水車内部にサボニウス型ロータを設置して混合水 車とした場合については，北風ら(2)や Kyozuka ら(3)等比 較的多くの報告がなされている。占有空間自体は水車単 体と同じであるが，サボニウス型ロータでは起動性は向 上するが高周速比域で抵抗となるため，広い周速比での 性能向上は期待できない。一方，直線翼ダリウス型風車 において，風車内部に円柱状のロータを設置することで 翼周りの流れの剥離を抑制し，風車全体のパワー係数が 
向上することが確認されている(4)。今回はそれをヒント にして，水車の内部に円柱形状の整流ガイドを設置する ことで性能向上が図れないかの検討を行った。円柱であ れば形状が単純なため, 比較的低コストで設置すること が可能であると考えられる。また風車では風向きが変化 するため, 風向依存性の観点からガイド形状は回転対称 な形状が望ましいが, 水車, 特に小水力発電においては, 流入方向が流路形状により確定しているため, ガイド形 状の自由度が高い。そこで，円柱と同様の剥離抑制効果 を残しつつも，より流路抵抗が小さい楕円柱型の整流ガ イドについても設置角度及び扁平率を変えて水車性能の 比較検討を行った。本論文では, 回流水槽を用いた水車 のトルク測定実験の結果と, 流れ場の詳細を調べるため に実施した流れの非定常三次元数值シミュレーションの 結果について報告する。

\section{2.トルク測定実験}

\section{1 実験装置と方法}

Fig. 1 にトルク測定実験に使用した水車の概略図を示 す。翼型は対称翼であるNACA0018 を採用し, 翼弦長 76.7 $\mathrm{mm}$, 翼スパン長さ $150 \mathrm{~mm}$ とした。翼の製作には, 光造 形式 3D プリンタ (3DSYSTEMS, Projet 3510 HD Plus) を使用し，スパン方向に積層する形で製作した。その際， 材料節約のために内部に中空の領域を設け，加工時間を 考慮して翼スパン方向に $25 \mathrm{~mm}$ ずつの 6 パーツに分けて 出力して M3 の全ネジボルトとナットで結合させた。た だし, 出力したパーツそのままでは, パーツ間の隙間や 積層痕が段差として残るため, 翼表面にアルミテープを 巻き付けることで表面粗さの低減を図った。また水車直 径 $d$ は $300 \mathrm{~mm}$ とし, 翼の固定と翼端の影響軽減のため, 上下に直径 $340 \mathrm{~mm}$, 厚さ $5 \mathrm{~mm}$ のアクリル円板を取り付 けている。ただし下側の円板については, 後述のガイド を設置するために, 中央に直径 $170 \mathrm{~mm}$ の穴が開いたド 一ナツ状になっている。また，ガイドを設置する空間の 確保のため, 回転軸は上側の円板にのみ接続されており, 水車内部を貫通してはいない。

Table 1. Model data.

\begin{tabular}{|l|c|c|c|c|}
\hline $\begin{array}{c}\text { Model } \\
\text { name }\end{array}$ & $\begin{array}{c}\text { Height } \\
h_{g}[\mathrm{~mm}]\end{array}$ & $\begin{array}{c}\text { Major axis } \\
\text { length } \\
2 l_{a}[\mathrm{~mm}]\end{array}$ & $\begin{array}{c}\text { Minor axis } \\
\text { length } \\
2 l_{b}[\mathrm{~mm}]\end{array}$ & $\begin{array}{c}\text { Flattening } \\
f[-]\end{array}$ \\
\hline Without & - & - & - & - \\
\hline Cylinder & 140 & 150 & 150 & 0 \\
\hline Ellipse A & 140 & 150 & 125 & 0.17 \\
\hline Ellipse B & 140 & 150 & 100 & 0.33 \\
\hline Ellipse C & 140 & 150 & 75 & 0.50 \\
\hline Ellipse D & 140 & 150 & 50 & 0.67 \\
\hline
\end{tabular}

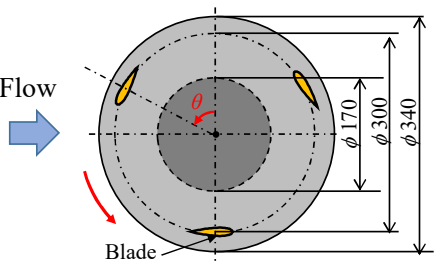

(a) Top view

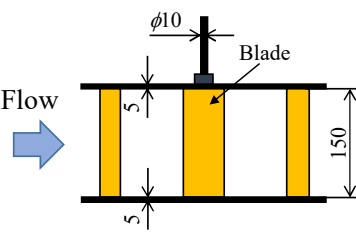

(b) Side view
Fig. 1. Schematics of water turbine.

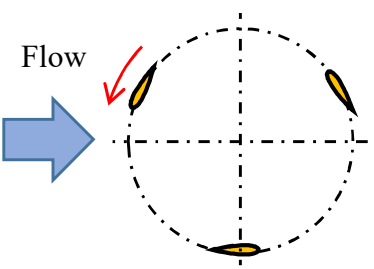

(a) Without

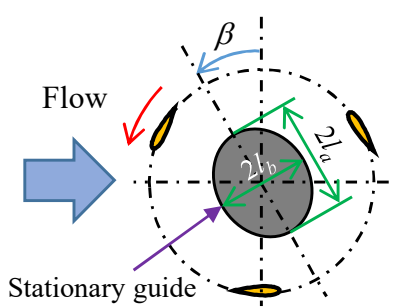

(c) Ellipse A

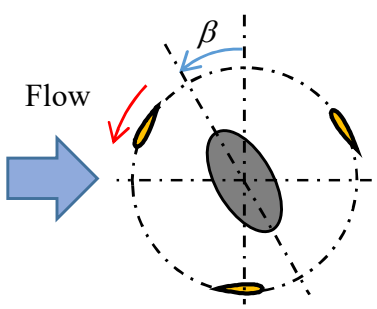

(e) Ellipse C

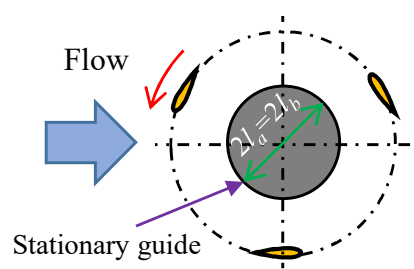

(b) Cylinder

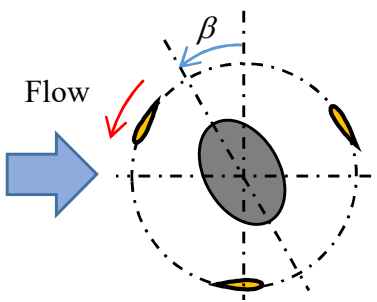

(d) Ellipse B

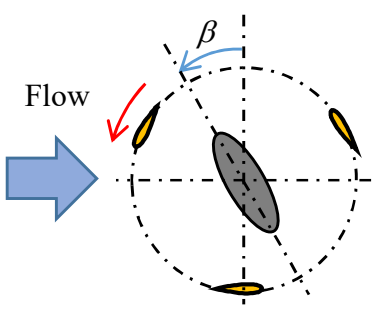

(f) Ellipse D
Fig. 2. Schematics of each model.

Fig. 2 にガイドを設置した各モデルの模式図, Table 1 にその諸元を示す。表中の扁平率 $f$ は, 長軸の長さを $2 l_{a}$, 短軸の長さを $2 l_{b}$ として次式で定義される。

$$
f=1-\frac{l_{b}}{l_{a}}
$$

ガイド比（=ガイドの長軸の長さ/水車直径）について は 0.5 の条件で固定した。各ガイドはテストセクション 下部に設置した支柱に固定することで供試水車の内部に 配置されている。また水車上面とのクリアランス確保の ため, 高さは全て翼スパンよりも短い $140 \mathrm{~mm}$ で統一し ている。ガイドについては，レーザー加工機（コムネッ ト, Spirit 40W）で $10 \mathrm{~mm}$ 厚のアクリル板から円または 楕円の断面形状を切り出し, 14 枚積層して接着した後, 側面にアルミテープを巻き付けることで製作した。なお， 楕円柱型ガイドについては，主流に相対する向きによっ て流れ場が変わるため, ガイドの長軸が主流と直交する 


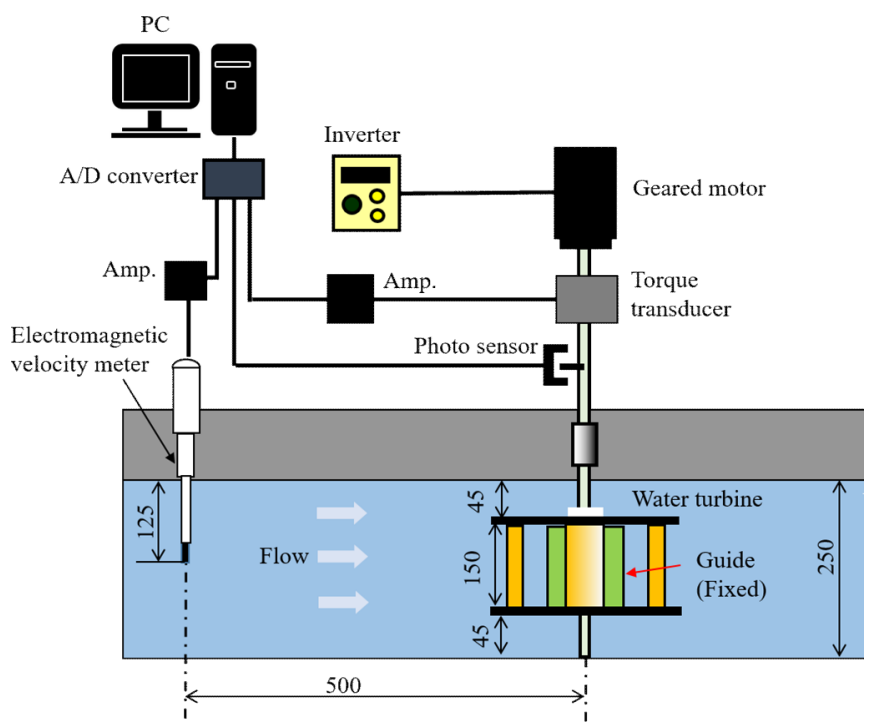

Fig. 3. Schematic of experimental setup.

状態を設置角 $\beta=0 \mathrm{deg}$ として, $0 \sim 150 \mathrm{deg}$ まで $30 \mathrm{deg}$ 刻 みで変化させて同様の計測を行った。

Fig. 3 に実験装置の模式図を示す。ポンプ（イワキ, MX400CV6-2）及び船外機（エレキモーター, od278）に より駆動する水平に設置された回流水槽内に, 幅 $500 \mathrm{~mm}$, 長さ $800 \mathrm{~mm}$ のテストセクション部が設けられている。 テストセクションの上から回転軸が伸びる形で供試水車 が設置され，水車の下から各ガイドを挿入できるように なっている。供試水車の回転軸は, トルク変換器（共和 電業，TP-2KCE）を介して水車駆動用のギヤードモータ

（オリエンタルモーター，51K90GU-SF+5GU9KB）に接 続されている。トルク変換器の出力信号は, 動ひずみ計

(共和電業, $\mathrm{DPM}-713 \mathrm{~B}$ ), $\mathrm{AD}$ 変換器 (CONTEC, AI1608AY-USB）を介してPCに取り込まれる。また水車の 回転数は, モータに接続したインバータにより調整し, 回転軸に取り付けた遮光板の通過によりパルス信号を出 力するフォトセンサ (Panasonic, PM-L24) を用いて計測 した。またテストセクションに流入する流速は, 前述の ポンプに接続したインバータにより調節し, 今回は流入 流速を $0.35 \mathrm{~m} / \mathrm{s}$ に設定した。その際, 水車上流 $500 \mathrm{~mm}$, 水面から深さ $125 \mathrm{~mm}$ の位置に設置した電磁流速計（ケ ネック，VM-901H+VMT-200-04P）を用いて流速を計測 した。なお今回は水深を $250 \mathrm{~mm}$ とした。

\section{2 評価指標}

今回は主流速度を一定に保ったまま, 水車の回転数を 調整して周速比入を設定し, その周速比入においてトルク を測定した結果からパワー係数 $C_{P}$ を算出し, 各ガイドの 水車性能の比較を行った。なお, 周速比 $\lambda$ 及びパワー係 数 $C_{P}$ は次式で定義される。

$$
\lambda=\frac{U_{b}}{U_{\text {in }}}
$$

$$
C_{P}=\frac{2 \omega}{\rho U_{i n}^{3} A}
$$

ここで, $U_{\text {in }}$ は主流速度 $(=0.35 \mathrm{~m} / \mathrm{s}), U_{b}$ は翼の周速 度を示している。また $\rho$ は水の密度, $A$ は水車の前方投影 面積（=直径 $0.3 \mathrm{~m} \times$ スパン $0.15 \mathrm{~m}=0.045 \mathrm{~m}^{2}$ ), $\omega$ は角 速度, $T$ は平均トルクを示している。トルクの測定はサ ンプリングレート $30 \mathrm{~ms}$ の設定で $30 \mathrm{~s}$ 間の計測を行い, その平均值を $T$ として採用した。

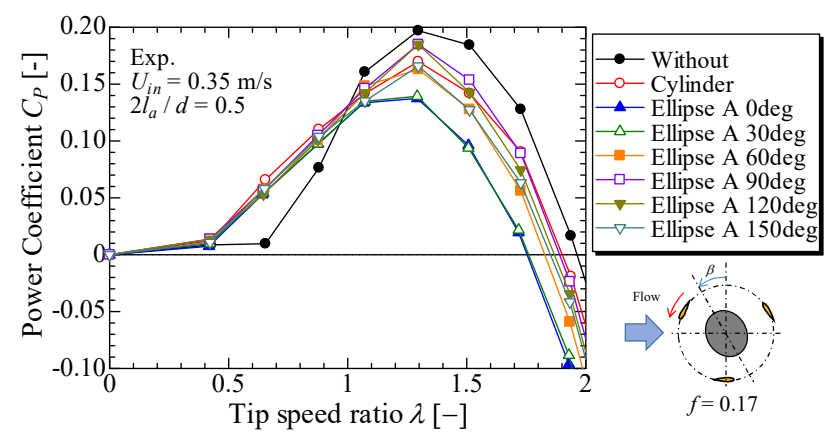

(a) Ellipse A

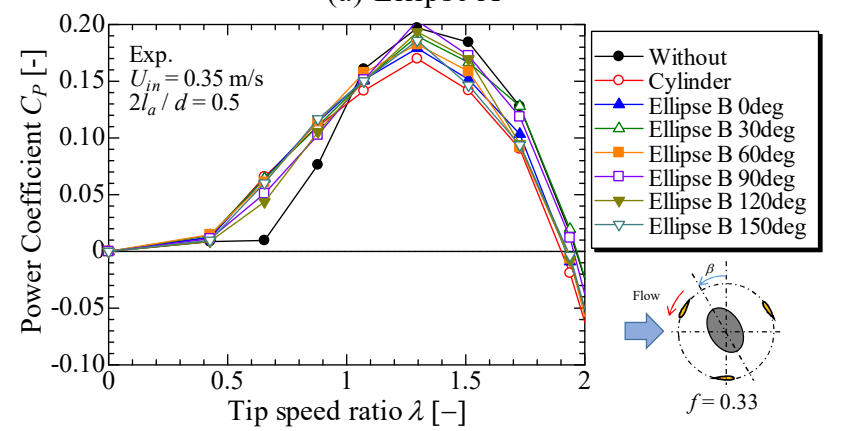

(b) Ellipse B

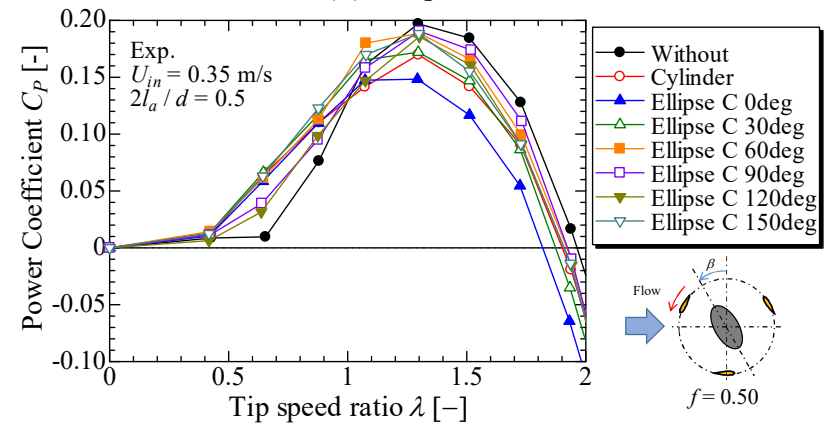

(c) Ellipse C

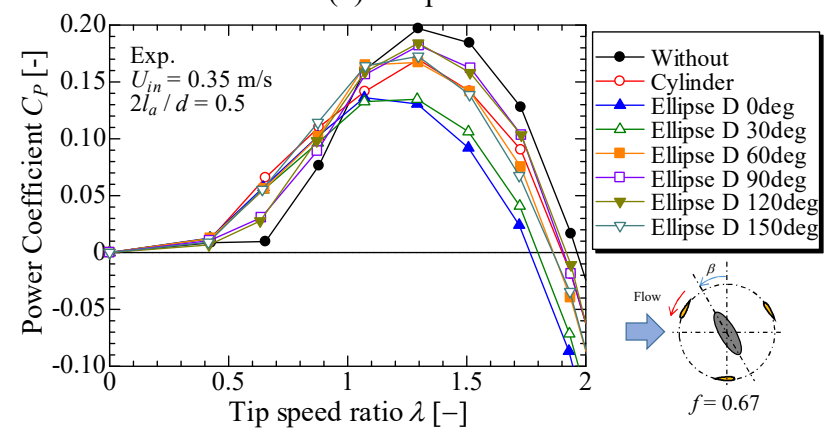

(d) Ellipse D

Fig. 4. Tip speed ratio $\lambda$ vs. power coefficient $C_{P}$. (Experimental results) 


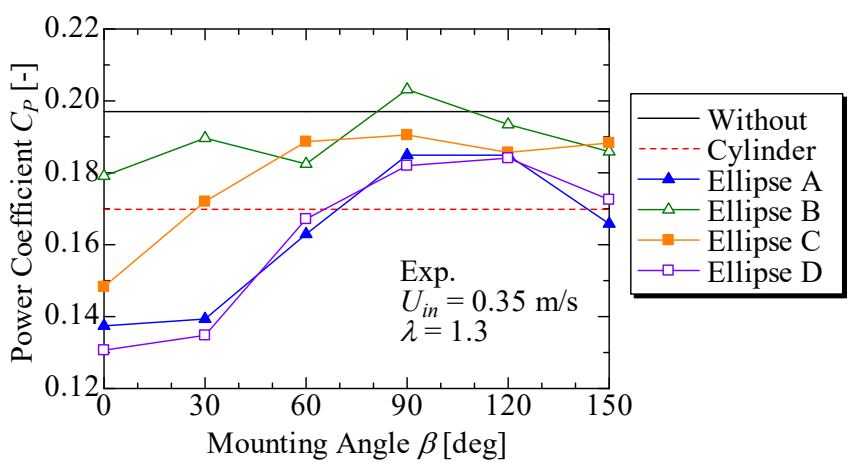

Fig. 5. The relationship between mounting angle $\beta$ and power coefficient $C_{P}$. (Experimental results, $\lambda=1.3$ )

\section{3 測定結果}

Fig. 4 に上記計測により得られた周速比 $え$ と゚ワー係 数 $C_{P}$ の関係を示す。Fig. 4 より, $\lambda$ が 1 以下の低周速比 では, 円柱型ガイドを取り付けた場合, ガイド無し

(Without) に比べて $C_{P}$ が向上しており， $\lambda=0.65$ で約 $58 \%$ 向上している。楕円柱型ガイドにおいても同様に, いずれの条件でも低周速比ではガイド無しよりも $C_{P}$ が 向上している。その向上の度合いは, 扁平率 $f$ が低いほ ど設置角 $\theta$ の違いによる差はほぼ見らない。また $C_{P}$ が大 きく向上しているものはいずれも值に大差なく, 円柱型 ガイドとほぼ同程度の值を示す。一方入が 1 より大きい 高周速比域を見ると, 円柱型ガイドではガイド無しより も $C_{P}$ が低下し， $\lambda=1.3$ で約 $17 \%$ 低下している。楕円柱 型ガイドでも, 高周速比においてはガイド無しより $C_{P}$ が 低下寸るが, 条件によっては円柱型ガイドほじ低下せず, ガイド無しと同程度の值を維持していることが見て取れ る。従って, 設置角 $\theta$ や扁平率 $f$ を適切に設定した楕円 柱型ガイドであれば, 低周速比でのパワー係数の増加と, 高周速比でのパワー係数の低下を低減することが期待で き, 幅広い周速比の範囲で有効に機能することが見込ま れる。

いずれのモデルもパワー係数 $C_{P}$ のピークは $\lambda=1.3$ 付 近であることから， $\lambda=1.3$ の時のパワー係数の值を比較 すると Fig. 5のようになる。Fig. 5 より，いずれも設置角 $\beta=90 \mathrm{deg}$ の時に最大パワー係数をとることが分かる。 また Ellpse B では, すべての設置角の範囲で円柱型ガイ ドよりも最大パワー係数が大きく，他の楕円柱型ガイド と比べても高いパワー係数を示している。よって，今回 検討した条件範囲内では, Ellpse B (扁平率 $f=0.33$ ), 設 置角 $\beta=90 \mathrm{deg}$ がパワー係数 $C_{P}$ を向上させるのに最適で あると考えられ，円柱型ガイドと比べると $\lambda=1.3$ で約 $12 \%$ 向上する。

\section{3. 流れの数值シミュレーション}

\section{1 計算条件と計算方法}

実験では流れ場やトルクの発生部位の詳細を調べるこ

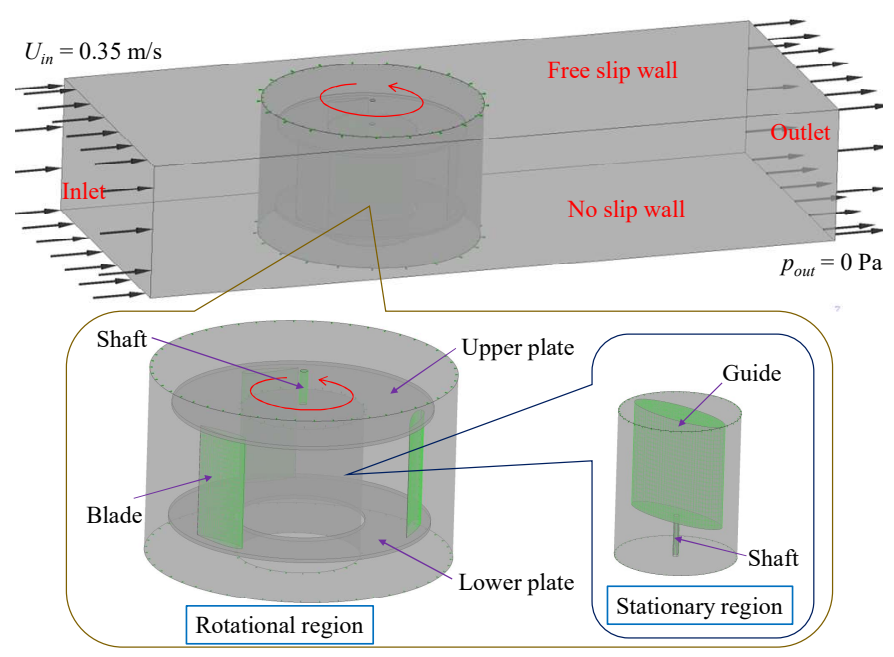

Fig. 6. Schematics of calculation conditions.
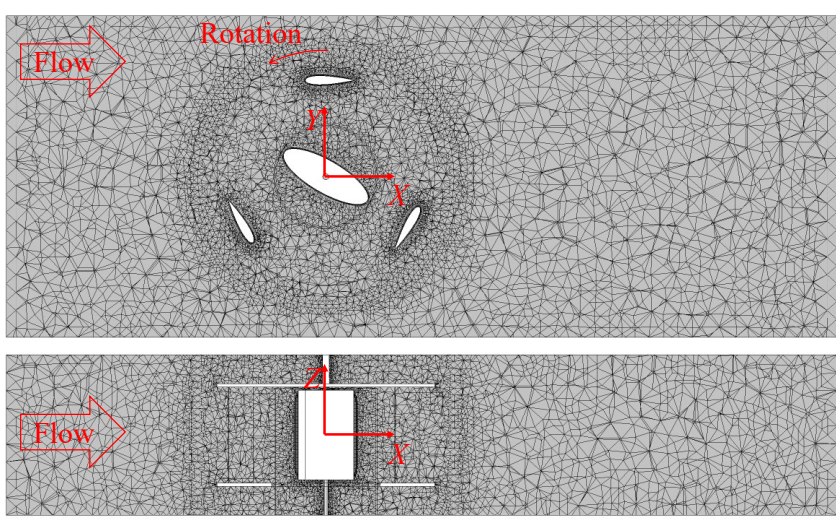

Fig. 7. Cross sections of calculation mesh.

とは困難であるため, 数值シミュレーションにより同様 の流れ場を再現して検討した。今回は上述の実験結果よ り楕円柱型ガイドで最も有効と判断した Ellipse B（扁平 率 $f=0.33$, 設置角 $\beta=90 \mathrm{deg})$ について，ガイド無し

(Without）及び円柱型ガイド（Cylinder）と比較した。

Fig. 6 に計算条件の模式図を示す。計算領域は実験装 置のテストセクションに合わせて流路幅 $500 \mathrm{~mm}$, 水深 $250 \mathrm{~mm}$ とし, 流路長さは水車の中心から上流に $500 \mathrm{~mm}$, 下流に $800 \mathrm{~mm}$ の計 $1300 \mathrm{~mm}$ とした。この直方体の静止 領域の内部に直径 $400 \mathrm{~mm}$, 高さ $250 \mathrm{~mm}$ の回転領域と, その内部にガイドを取り囲むように直径 $160 \mathrm{~mm}$ ，高さ 197。 $5 \mathrm{~mm}$ の静止領域を設けた。また流入部で一定の流 入流速 $U_{\text {in }}=0.35 \mathrm{~m} / \mathrm{s}$, 出口部で圧力 $p_{\text {out }}=0 \mathrm{~Pa}$ を与え, 流路の底面及び側面には No slip 条件, 上面は Free slip 条 件を課した。

Fig. 7 に使用した計算メッシュの断面図の一例を示す。 計算メッシュの作成にはメッシュ作成ソフトウェア Pointwise (Pointwise Inc.) を使用した。また境界層部の空 間分解能を稼ぐため，翼表面及びガイド表面のメッシュ からは初期高さ $0.05 \mathrm{~mm}$, 成長率 1.3 で 5 層の押出を行 い, いずれも総要素数 50 万程度とした。なお, 計算メッ 
シュはガイドを囲む静止領域以外は全て共通のものを用 いた。流れ場の計算及びポスト処理には, 有限体積法に 基づく汎用熱流体解析ソルバーである ANSYS CFX

（ANSYS Inc.）を使用した。水の物性值については, ANSYS CFX のライブラリの值を使用した。また 1 回転 あたり 360 ステップとして $1 \mathrm{deg}$ 毎の計算を 3 回転分実 施した。なお，乱流モデルについては, Daróczyら(5)によ りダリウス型風車において各モデルの比較検討が実施さ れており, その結果を参考にして, 今回は SST モデルを 使用した。

\section{2 各モデルでのパワー係数の比較}

数值シミュレーション結果の妥当性の検証のため, 周 速比とパワー係数の関係を実験結果と比較する。Fig. 8 に その結果を示す。Fig. 8 より, 数值シミュレーションの結 果は全体的に実験結果よりも高いパワー係数を示した。 これは計算コストの観点から各部固定用のボルトやシャ フトホルダー等の実験装置の細部までは峳密に再現して いないことに加えて, 水面の変動を考慮していないこと も差異の要因と考えられる。しかし, 周速比に対するパ ワー係数の変化の全体的な傾向は実験結果とほぼ一致し ており，低周速比では円柱型ガイドのパワー係数が高い が楕円柱型ガイドと同程度であり，高周速比では円柱型 ガイドのパワー係数が低いことが確認できる。よって本 計算結果は，定性的には妥当であると言える。

\section{3 翼一枚の 1 回転中のトルク変動}

ガイド無し, 円柱型ガイド，楕円柱型ガイド B（設置 角 $\beta=90 \mathrm{deg} ）$ の回転中に翼一枚に発生するトルクの変 化を示すと Fig. 9，10のようになる。Fig. 9 は低周速比域 の代表例として周速比 $\lambda=0.8$ の結果を, Fig. 10 は高周速 比域の代表例として周速比 $\lambda=1.3$ の結果をそれぞれ示し ている。なお横軸は方位角 $\theta$ を表しており，図中に示す 通り，主流に正対する位置に翼が来た時を $\theta=0 \mathrm{deg}$ とし ている。また翼は 3 枚であるが，それらは位相が $120 \mathrm{deg}$ ずれているだけでトルクの変動波形自体は同じである。

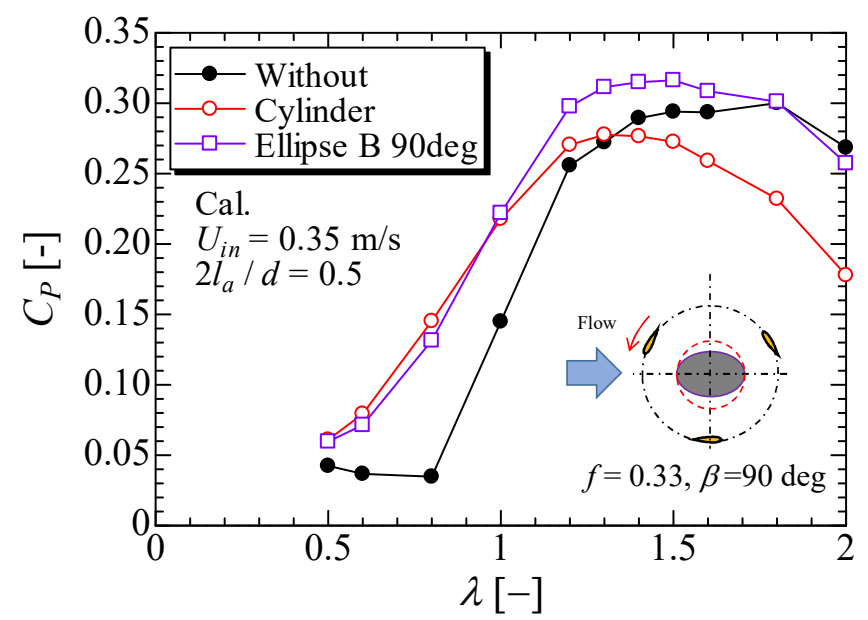

Fig. 8. Tip speed ratio $\lambda$ vs. power coefficient $C_{P}$. (Calculation results)

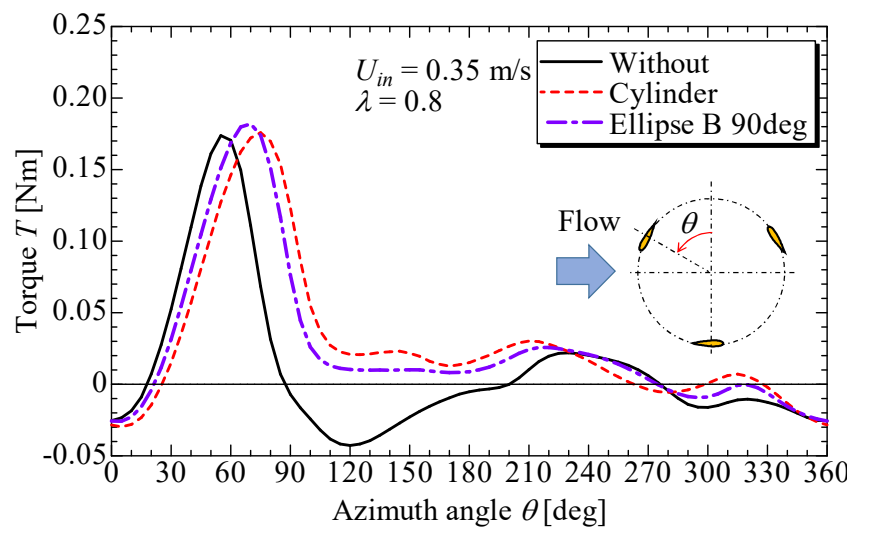

Fig. 9. The changes of torque on a wing.

(Calculation results, $\lambda=0.8$ )

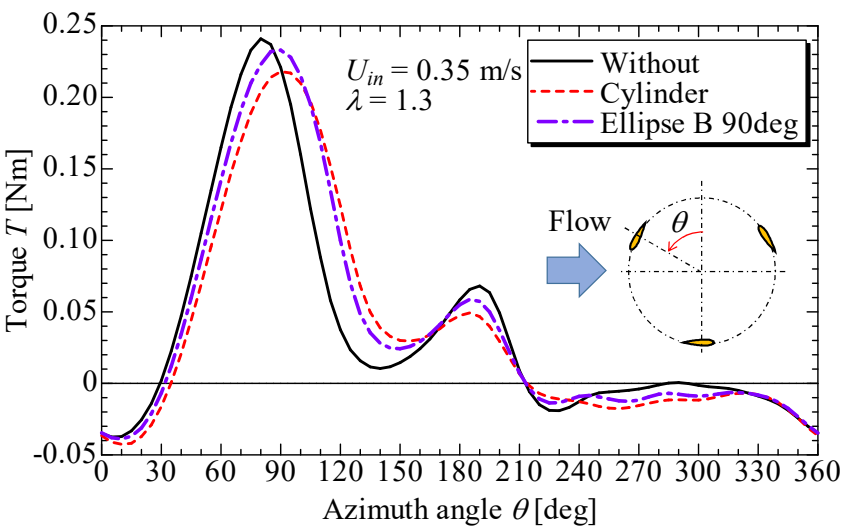

Fig. 10. The changes of torque on a wing.

(Calculation results, $\lambda=1.3$ )

Fig. 9 より, ガイド無しではトルクの最大值が最も低 く, $\theta=90 \sim 200 \mathrm{deg}$ 範囲でトルクが負の值を示してい る。これに対し，いずれのガイドを付けた場合でもトル クの最大值はガイド無しよりも大きく, また $\theta=90 \sim 200$ deg でトルクが正の值をとっていることが分かる。加え て $\theta=60 \sim 230 \mathrm{deg}$ の広い範囲でガイド無しよりも高いト ルクを維持している。すなわち低周速比では，ガイドを 設けることでトルクの最大值が増大し，さらに負のトル クの発生を抑制しつつガイド無しよりも高いトルクを維 持していることから，一回転の平均トルクの值がガイド 無しより増加する。これはガイドの存在により, 翼に流 入する流れが変化するためであると考えられる。

一方高周速比では, Fig. 10 よりトルクの最大值はガイ ド無しが最も高く, 円柱型ガイドが最も低くなっている ことが分かる。また円柱型ガイドでは $\theta=210 \mathrm{deg}$ 以降の 負のトルクを生じている区間で比較的大きな負の值をと る範囲が広いことから, 一回転の平均トルクにすると他 の場合よりも低下すると考えられる。なお楕円柱型ガイ ドでは，トルクの最大值はガイド無しに比べると低いも のの，ガイド無しでトルクが低下する $\theta=90 \sim 170 \operatorname{deg}$ の 範囲でガイド無しよりも高いトルクを維持していること から，一回転の平均トルクとしてはガイド無しよりも向 
上したものと考えられる。

\section{4 流速分布及び圧力分布}

ガイド無し，円柱型ガイド，楕円柱型ガイド $\mathrm{B}(\beta=90$ deg）について, 速度分布及び圧力分布を低周速比と高周 速比のそれぞれにおいて比較する。直線翼ダリウス型水 車であるため流れはほぼ二次元的であることから，ここ では翼幅の中央の断面で考える。

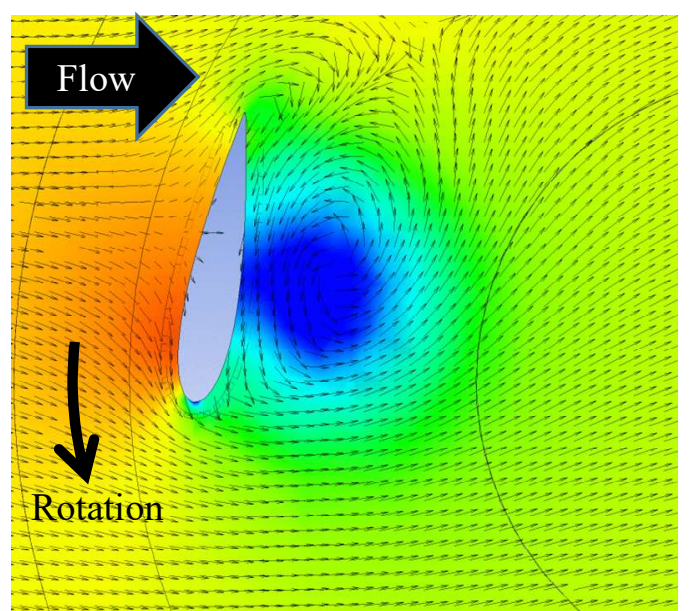

(a) Without

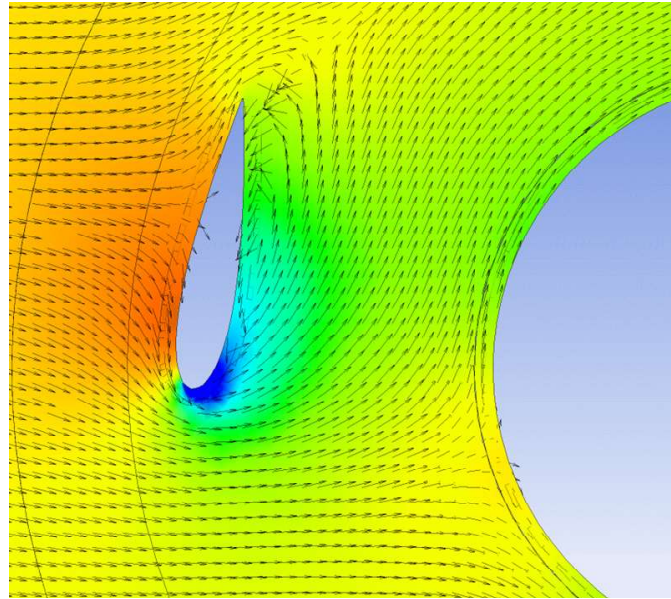

(b) Cylinder

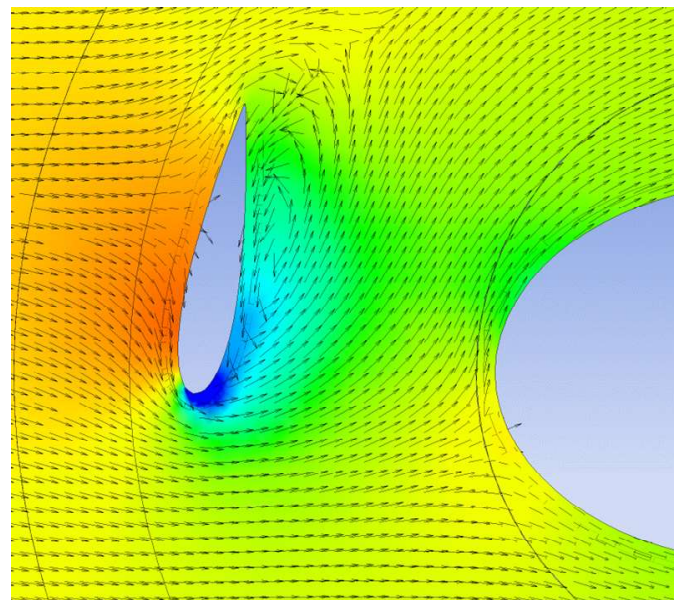

$p[\mathrm{~Pa}]$

(c) Ellipse $\mathrm{B}(\beta=90 \mathrm{deg})$

Fig. 11. Velocity and pressure distribution. (Calculation results, $\lambda=0.8, \theta=80 \mathrm{deg}$ )
まず低周速比の代表例として，ここでは $\lambda=0.8$ の場合 を考える。Fig. 9 においてトルクの差が比較的顕著な $\theta=$ $80 \mathrm{deg}$ の時の速度分布及び圧力分布を Fig. 11 に示す。な お図中には矢印で速度分布を示し, カラーコンターで圧 力を表示しており，負圧が大きいほど青く表示されるよ うになっている。Fig. 11 より，ガイド無しでは翼に当た った流れが大きく剥離して, 回転中心側の面に負圧の領

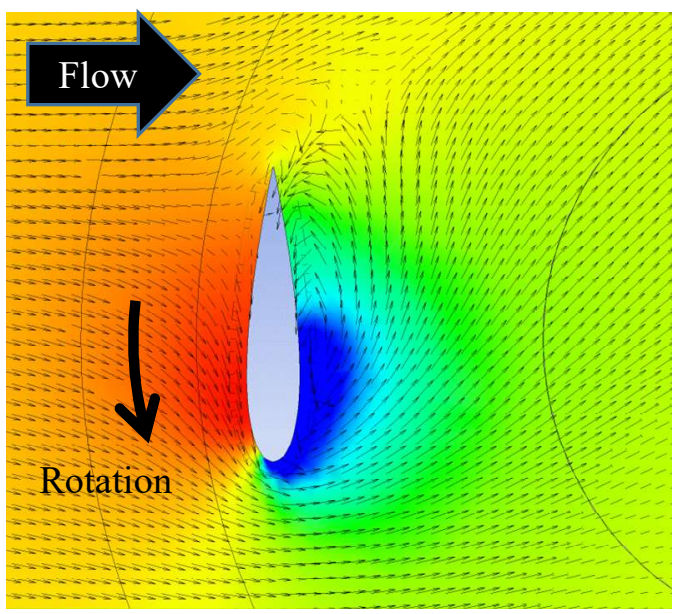

(a) Without

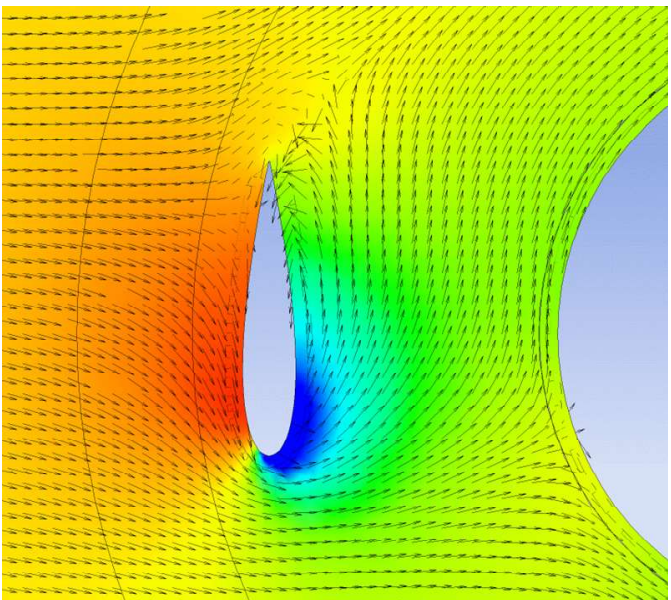

(b) Cylinder

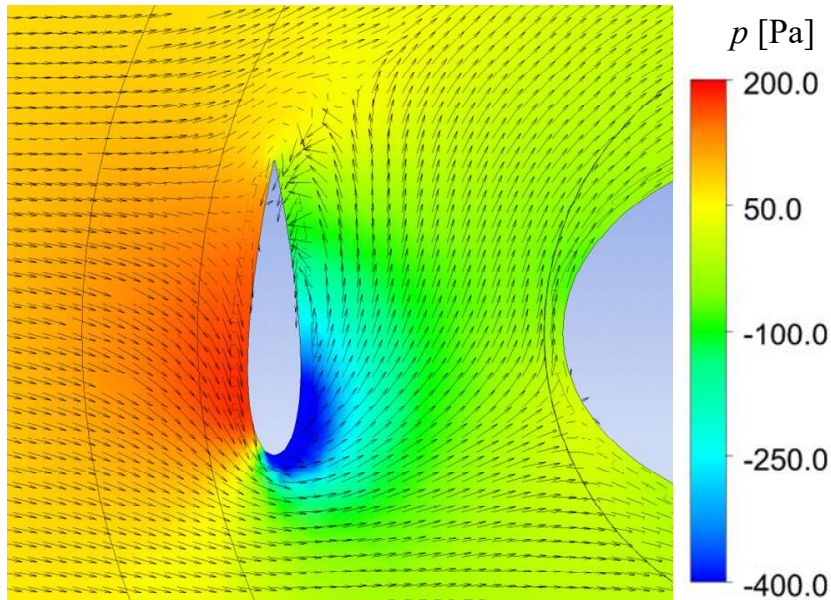

(c) Ellipse $\mathrm{B}(\beta=90 \mathrm{deg})$

Fig. 12. Velocity and pressure distribution.

(Calculation results, $\lambda=1.3, \theta=90 \mathrm{deg}$ ) 
域が生じているが，位置的に翼の回転方向のトルクには あまり寄与しないと考えられる。一方, 円柱型ガイドで はガイドの存在により翼周りの流れの剥離が抑制され, 翼の前縁付近に負圧の領域が形成されていることが分か る。この位置での負圧は回転方向のトルクを生じるため, 円柱型ガイドのパワー係数が増大したものと考えられる。 また，楕円柱型ガイドにおいても，翼周りの流れ場は円 柱型ガイドの場合と同様である。

次に高周速比の代表例として $\lambda=1.3$ の場合を考えると， Fig. 10 においてトルクの差が比較的顕著な $\theta=90 \operatorname{deg} の$ 時の速度分布及び圧力分布は Fig.12のようになる。Fig. 12 を見ると, いずれもこのタイミングでは翼前縁付近に 負圧の領域が生じていることから，回転トルクを発生し ていることがわかる。ただしガイド無しでは，翼の回転 中心側の面で流れが大きく剥離して回転トルクを生じに くい翼の中腹部にまで負圧の大きい領域が広がっている。 これに対しガイドがある状態では，流れの剥離が抑制さ れ, 翼前縁付近に負圧の大きい領域があり, より回転卜 ルクを得やすい状態になっている。

Fig. 8 において $\lambda=1.3$ でパワー係数に明確な差が生じ ていたにもかかわらず，Fig. 12 ではガイド間の差が顕著 に見られなかったため, 翼面上の圧力分布を比較した結 果をFig. 13 に示す。ここで横軸は翼弦長で正規化された 翼弦方向の位置を表しており，0 が前縁，1 が後縁となっ ている。Fig. 13 より, 翼の外側の面での圧力はいずれも ほぼ同じであるが，内側の面ではガイド無しのみトルク に寄与しない翼中腹部で負圧が大きくなっている。また 翼前縁近傍の負圧のピーク值は，ガイド無しで約-18.1 $\mathrm{kPa}$ ，円柱型ガイドで約-16.7 kPa，楕円柱型ガイドで約-

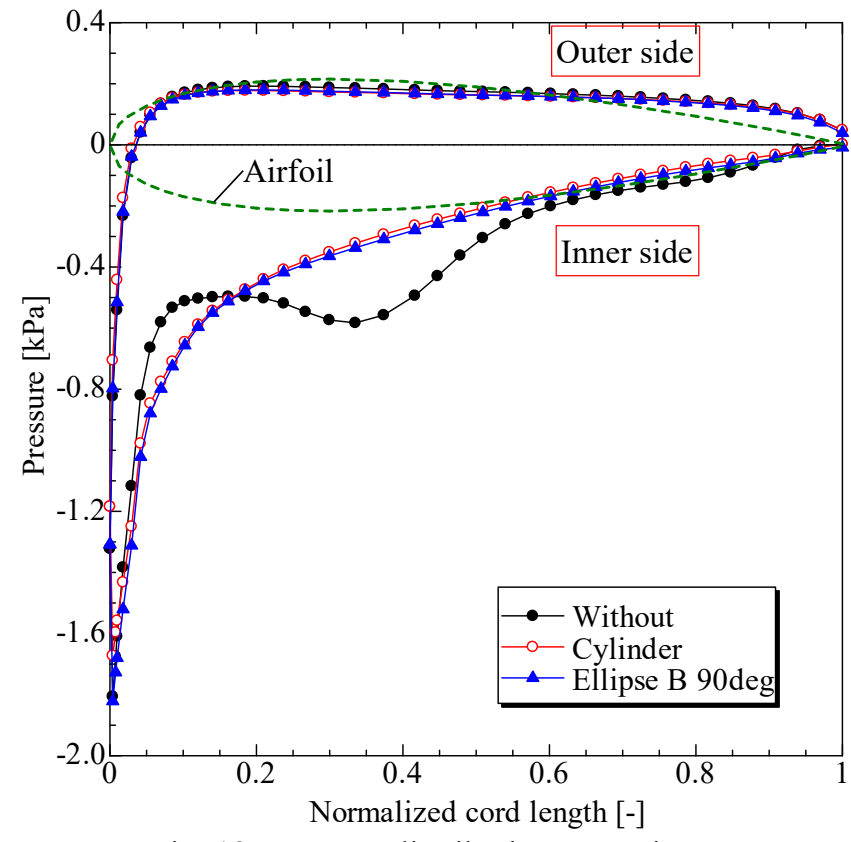

Fig. 13. Pressure distribution on a wing.

(Calculation results, $\lambda=1.3, \theta=90 \mathrm{deg}$ )
$18.2 \mathrm{kPa}$ となっている。この位置での大きな負圧はトル クの発生に貢献することから, 楕円柱型ガイドでトルク が向上したと考えられる。

以上のことから, ガイドの設置により翼周りの流れ場 が変化し, 扁平率及び設置角を適切に設定した場合, 翼 前縁付近に強い負圧が発生することでトルクが増大し, 結果的にパワー係数の増大につながると考えられる。

\section{4. 今後の展望}

水車内部に楕円柱型ガイドを設置することにより，幅 広い周速比でパワー係数を向上させることに成功した。 ただし, パワー係数の理論限界が 0.593 (周速比 $\lambda=1.3$ で は 0.45 程度）であるのに対し, 現状は最大でも 0.2 程度 であるため, 更なる改良の余地があると考えられる。今 後の展望としては, 円柱型または楕円柱型ガイドを水車 中心に対して偏心させて設置した場合で同様の実験及び 数值シミュレーションを行うことを検討している。

\section{5.まとめ}

直線翼ダリウス型水車の性能向上を図るため, 水車内 部に円柱型または楕円柱型ガイドを設置した場合につい て, トルク測定実験及び流れの三次元非定常数值シミュ レーションを実施した結果，以下のことが分かった。

(1) 円柱型ガイドを設置すると, パワー係数 $C_{P}$ は低周 速比域ではガイド無しに比べて向上するが, 高周速 比域ではガイド無しより低下する。

(2) 低周速比域では, 今回検討したいずれのガイドもガ イド無しよりも $C_{P}$ は向上する。中でも円柱型ガイ ドが最も高い $C_{P}$ を示し, 周速比 $\lambda=0.65$ ではガイ ド無しに比べて約 $58 \%$ 向上する。ただし, 扁平率 $f$ 及び設置角 $\beta$ を適切に設定した楕円柱型ガイドであ れば，円柱ガイドと同程度の $C_{P}$ を示す。

(3) 高周速比域では, 楕円柱型ガイドを適切な設置角 $\beta$ で設置すれば，ガイドなしと同程度まで $C_{P}$ の低下 を軽減できる。 $f=0.33$ の楕円柱型ガイドを $\beta=90$ $\operatorname{deg}$ で設置した場合， $\lambda=1.3$ で円柱型ガイドよりも 約 $12 \% C_{P}$ が向上する。

（4）楕円柱型ガイドは, 円柱型ガイドよりも広い周速比 $\lambda$ の範囲で $C_{P}$ の向上が期待できる。今回検討した 条件の範囲では, $f=0.33$ の楕円柱型ガイドを $\beta=90$ $\operatorname{deg}$ で設置した場合が最も効果的である。

（5）ガイドを設置すると翼周りの流れ場が変化し, 特に 適切なガイドを設置すると, 翼の回転中心側の面で 流れの剥離が抑制されることで回転トルクを生む 翼前縁付近に負圧の大きい領域が発生する。

$$
\text { 文献 }
$$

(1) 別府克哉, 大賀博文, 林則行:「ダリウス型水車の出力特性に及ぼ 
すディフューザ寸法の影響」, 電気関係学会九州支部連合大会講演 論文集，Vol. 2012，01-2P-02，2012

（2）北風裕教, 村上秀隆, 堀義則:「潮流発電技術を応用した小水力発 電システムの開発」, 産業応用工学会論文誌, Vol. 4, No. 1, pp. 16,2016

(3) Yusaku Kyozuka : “An experimental study on the Darrieus-Savonius turbine for tidal current power generation", Journal of Fluid Science and Technology, Vol. 3, No. 3, pp. 439-449, 2008

（4）川口清司, 春山幸浩:「円柱型ガイドを用いた直線翼ダリウス型風 車の性能向上」, 日本機械学会論文集, Vol. 84, No. 865, p.18-00212, 2018

(5) László Daróczy, Gábor Janiga, Klaus Petrasch, Michael Webner, Dominique Thévenin : "Comparative analysis of turbulence models for the aerodynamic simulation of H-Darrieus rotors", Energy, Vol. 90, pp. $680-690,2015$

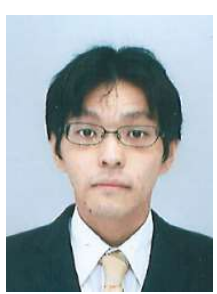

加瀬 篤志

2007 年 3 月関西大学工学部機械システム工学科 卒業。同年 4 月同大学院理工学研究科博士課程前 期課程入学, 2009 年 3 月修了。同年 4 月同大学院 博士課程後期課程入学, 2012 年 3 月修了, 博士 (工 学)。同大学研究員等を経て 2015 年 4 月富山大学 大学院理工学研究部 (工学) 助教, 現在に至る。血 流や羽ばたき翼等の生物流体関連の研究の他, 近 年は主に風車, 水車, 送風機等の研究に従事。

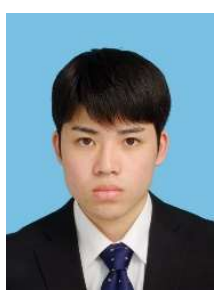

井出 慎輝

2019 年 3 月富山大学工学部機械知能システム工 学科卒業。同年 4 月同大学大学院理工学教育部機 械知能システム工学専攻入学, 現在に至る。直線翼 ダリウス型水車の性能向上に関する研究に従事。

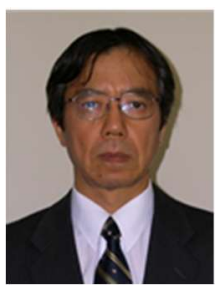

\section{川口＼cjkstart清司}

1979 年 3 月金沢大学工学部機械工学科卒業。同 年 4 月日本電装㑣（現株デンソー）入社，2001 年 4 月富山大学に移り, 現在富山大学大学院理工学研 究部 (工学) 教授, 工学博士。ファン騒音の低減, 再生可能エネルギー, アルミ水素エネルギー等, 熱 流体の研究に従事。 